\title{
Morphological Variation in Absorptive Roots in Downy Birch (Betula pubescens) and Norway Spruce (Picea abies) Forests Growing on Drained Peat Soils
}

\author{
Azadeh Rezapour ${ }^{1, *}$, Marika Truu ${ }^{2}$, Martin Maddison ${ }^{1}$, Gristin Rohula-Okunev ${ }^{1}$, Arvo Tullus ${ }^{1}$ (D), Veiko Uri ${ }^{3}$, \\ Ülo Mander ${ }^{1}$ (D) and Ivika Ostonen ${ }^{1}$ \\ 1 Institute of Ecology and Earth Sciences, University of Tartu, Vanemuise 46, 51003 Tartu, Estonia; \\ martin.maddison@ut.ee (M.M.); gristin.rohula-okunev@ut.ee (G.R.-O.); arvo.tullus@ut.ee (A.T.); \\ ulo.mander@ut.ee (Ü.M.); ivika.ostonen@ut.ee (I.O.) \\ 2 Institute of Molecular and Cell Biology, University of Tartu, Riia 23, 51010 Tartu, Estonia; marika.truu@ut.ee \\ 3 Institute of Forestry and Rural Engineering, Estonian University of Life Sciences, Fr. R. Kreutzwaldi 5, \\ 51006 Tartu, Estonia; veiko.uri@emu.ee \\ * Correspondence: azadeh.rezapour@ut.ee
}

check for

updates

Citation: Rezapour, A.; Truu, M.; Maddison, M.; Rohula-Okunev, G.; Tullus, A.; Uri, V.; Mander, Ü.; Ostonen, I. Morphological Variation in Absorptive Roots in Downy Birch (Betula pubescens) and Norway Spruce (Picea abies) Forests Growing on Drained Peat Soils. Forests 2022, 13, 112. https://doi.org/10.3390/ f13010112

Received: 20 December 2021

Accepted: 10 January 2022

Published: 13 January 2022

Publisher's Note: MDPI stays neutral with regard to jurisdictional claims in published maps and institutional affiliations.

Copyright: (C) 2022 by the authors. Licensee MDPI, Basel, Switzerland. This article is an open access article distributed under the terms and conditions of the Creative Commons Attribution (CC BY) license (https:// creativecommons.org/licenses/by/ $4.0 /)$.

\begin{abstract}
Peatland drainage based on ditch systems is a widely used forestry management practice in the boreal and hemiboreal forests to improve tree growth. This study investigated the morphological variation in absorptive roots (first- and second-order roots) across the distance gradient from the ditch with four sampling plots $(5,15,40$, and $80 \mathrm{~m})$ in six drained peatland forests dominated by Downy birch and Norway spruce. The dominating tree species had a significant effect on the variation in absorptive root morphological traits. The absorptive roots of birch were thinner with a higher specific root area and length (SRA and SRL), higher branching intensity (BI), and lower root tissue density (RTD) than spruce. The distance from the ditch affected the absorptive root morphological traits (especially SRA and RTD), but this effect was not dependent on tree species and was directionally consistent between birch and spruce. With increased distance from the ditch (from plot 5 to plot 80), the mean SRA increased by about $10 \%$ in birch and $5 \%$ in spruce; by contrast, the mean RTD decreased by about $10 \%$ in both tree species, indicating a potential shift in nutrient foraging. However, soil physical and chemical properties were not dependent on the distance from the ditch. We found a species-specific response in absorptive root morphological traits to soil properties such as peat depth, $\mathrm{pH}$, and temperature. Our results should be considered when evaluating the importance of morphological changes in absorptive roots when trees acclimate to a changing climate.
\end{abstract}

Keywords: absorptive roots; morphological variation; drained peatland forests; distance to ditch; Downy birch; Norway spruce

\section{Introduction}

Peatland drainage has been an essential component of forestry management practices in boreal and hemiboreal zones [1,2]. In Estonia, approximately $20 \%$ of the forests grow on peatlands, from which $14 \%$ are drained [3]. The artificial drainage in peatlands based on ditch networks was carried out to lower the water table level and promote aeration of the root zone [1]. Improved tree growth was observed as a result of peatland drainage in many boreal coniferous forests [4,5]. Much research has reported the stimulating role of distance from the ditch on tree growth; sites located near to the ditch result in a higher tree growth [6,7]. This is due to the enhanced aeration of the substrate and more rapid decomposition rate of organic matter, caused by lowered water table levels at distances near ditches [6,8]. Truu et al. [9] showed that the distance from drainage ditches affected soil microbial communities; however, such an effect was dependent on the dominant tree species and the specific site conditions. Fine roots (diameter $<2 \mathrm{~mm}$ ) are key peat-forming 
elements in peatland ecosystems [10] but are understudied in most trait-related research in peatland forest ecosystems. Most of the available research is concerned with studying fine root production, fine root growth, and phenology in forested peatlands [11,12], while very little is known about the morphology of fine roots, especially the absorptive roots (defined as first- and second-order roots) $[13,14]$ of trees growing in peat soils. These studies are also scarce in the drained peatland forests.

Absorptive roots with primary development and their ectomycorrhizal (ECM) fungal associates are the most physiologically active parts of the fine root system and are responsible for resource acquisition $[15,16]$. Absorptive roots with their small diameters and short lifespan are the most responsive component of the fine root system to changes in environmental factors [14,17]. Recent studies have shown that absorptive root morphological traits can vary widely across plant species [18] and soil nutrient patches, such as $\mathrm{pH}[19,20]$, carbon-to-nitrogen ratio $(\mathrm{C} / \mathrm{N})$, as well as available phosphorous $(\mathrm{P})$ [21], and water resources [22,23]. Growing evidence suggests that trees optimize their resource uptake by modifying absorptive root morphological traits $[18,24]$. Several root morphological traits have been commonly used as potential indicators of the resource acquisition efficiency of trees [25]. For example, specific root area (SRA) and specific root length (SRL) are used to evaluate the relationship between root resource acquisition and root construction costs [26,27]. A reduction in absorptive root diameter leads to increases in SRA and SRL, and finally to enhanced resource uptake and intensive growth [28,29]. Root tissue density (RTD) is associated with root lifespan and survival [28,30]. Branching intensity (BI), which is also referred to as branching pattern [31], root tip frequency [18], or specific root tip density [32], determines the plastic responses of the absorptive roots to nutrient patches, influencing water and nutrient uptake rates and function [33]. Overall, knowledge of the absorptive root morphological responses of trees growing at drained histosols is insufficient. Understanding the root response characteristics of trees at drained peatlands not only contributes to the elucidation of the resilience of different tree species, and drained peatland forest's functioning, but also helps in the better management of practices in peatland forest ecosystems.

Downy birch (Betula pubescens Ehrh.) is a deciduous early-successional pioneer tree species [34], and Norway spruce (Picea abies (L.) H.Karst.) is a late-successional conifer in boreal forests [35]. Recently, it has been shown that forests dominated by birch and spruce growing at initially similar drained histosols caused tree-species-specific changes in the soil chemical properties, including $\mathrm{pH}$, nitrogen content $(\mathrm{N})$, and $\mathrm{C} / \mathrm{N}$ ratio, and affected the soil bacterial communities [9]. This study investigated the effect of distance from the ditch on the morphological variation in absorptive roots at drained histosols of forests dominated by Downy birch and Norway spruce. The relationship of the absorptive root morphological variation in trees with forest stand and soil properties was assessed in this study. We proposed the following hypotheses: (1) the effect of distance from the ditch on absorptive root morphological variation is similar between birch and spruce; (2) the mean SRA and SRL increase, while the mean RTD decreases, with distance from the ditch.

\section{Materials and Methods}

\subsection{Characteristics of the Stands}

Six drained peatland forests in the Järvselja experimental forest area in the eastern part of Estonia were selected as study sites. Three stands dominated by Downy birch (Betula pubescens), and three stands dominated by Norway spruce (Picea abies), were under investigation in 2018. The abbreviations B1-B3 and S1-S3 were used for birch and spruce stands, respectively (Table 1). In each stand, a gradient with four sampling plots at distances of $5,15,40$, and $80 \mathrm{~m}$ from the ditch was selected. In one of the spruce stands (S3), the most distant plot from the ditch was at $40 \mathrm{~m}$, and plots at $5 \mathrm{~m}$ and $15 \mathrm{~m}$ were duplicated toward the next ditch at the same stand. A detailed description of the study sites and soil properties (Table 1) is available in a previously published paper by our team [9]. Briefly, all stands were classified as a drained Oxalis forest site type [36] and soils were classified as 
histosols [37]. All studied stands were drained in the 1970s using open-ditch networks [38]. At each sampling plot, the stand density (trees ha ${ }^{-1}$ ), stand basal area (BA, $\mathrm{m}^{2} \mathrm{ha}^{-1}$ ), and diameter at breast height $(\mathrm{DBH}, \mathrm{cm})$ of all trees with $\mathrm{DBH}>5 \mathrm{~cm}$ were measured on a $5 \times 20 \mathrm{~m}$ rectangular area (short side parallel to the distance gradient) (Table 2).

Soil temperature $\left(\mathrm{Ts},{ }^{\circ} \mathrm{C}\right)$ was measured at a $10 \mathrm{~cm}$ depth using a temperature logger (Comet Systems Ltd., Rožnov pod Radhoštem, Czech Republic). Soil volumetric water content $\left(\mathrm{VWC}, \mathrm{m}^{3} \mathrm{~m}^{-3}\right)$ was recorded monthly at a 5-10 $\mathrm{cm}$ depth by a ProCheck reader equipped with a GS3 sensor (Decagon Devices Inc., Pullman, WA, USA) at four sampling plots of all stands during April-October 2015 (Figure S1A-F). In addition, soil VWC was measured with water content reflectometers (model CS615, Campbell Scientific Inc., Logan, UT, USA) collected in $1 \mathrm{~min}$ intervals and stored as $10 \mathrm{~min}$ averages on a data logger (CR1000, Campbell Scientific Inc., Logan, UT, USA) at two sampling plots (5 and 40), of two stands (B2 and S1), in 2015 (Figure S1B,D) and 2018. In 2018, the mean annual air temperature during April-October was $13^{\circ} \mathrm{C}$, and the sum of monthly precipitations during August-October was $145 \mathrm{~mm}$ in Järvselja (Figure S2). To compare the precipitation dynamics in 2015 and 2018, the sum of monthly precipitation (mm) was averaged over ten weather stations in South Estonia (ilmateenistus.ee, accessed on 1 December 2021) for 2015 and measured at SMEAR station (smear.emu.ee, accessed on 1 December 2021) for 2018 (Figure S2). Soil physical-chemical parameters, including $\mathrm{pH}_{\mathrm{H} 2 \mathrm{O}}$, total C (TC), total $\mathrm{N}$ (TN), total P (TP), dissolved organic carbon (DOC), potassium (K), sulfur (S), water-soluble ammonium and nitrate nitrogen $\left(\mathrm{NH}_{4}-\mathrm{N}\right.$ and $\mathrm{NO}_{3}-\mathrm{N}$, respectively), and phosphate phosphorus $\left(\mathrm{PO}_{4}-\mathrm{P}\right)$ and calcium ion $\left(\mathrm{Ca}^{2+}\right)$ concentrations, were measured with the standard methods [39] in the lab of the Estonian Environmental Research Centre. In addition, the concentrations of dissolved organic carbon (DOC) were measured from soil using a Vario TOC equipped with a $\mathrm{TNb}$ detector (Elementar $\mathrm{GmbH}$, Langensenbold, Germany). All the chemical parameter values were presented based on dry soil.

Table 1. Geographical coordinates, and means \pm standard errors of fine root biomass and soil characteristics of the four sampling plots per stand (B1-B3, birch stands; S1-S3, spruce stands) and of the three replicate stands per birch and spruce [9].

\begin{tabular}{|c|c|c|c|c|c|c|}
\hline $\begin{array}{l}\text { Replicate } \\
\text { Stands }\end{array}$ & $\begin{array}{l}\text { Geographical } \\
\text { Coordinates }\end{array}$ & $\begin{array}{c}\text { Fine Root } \\
\text { Biomass }\left(\mathrm{g} \mathrm{m}^{-2}\right)\end{array}$ & $\begin{array}{l}\text { Peat Depth } \\
\text { (cm) }\end{array}$ & $\mathrm{pH}_{-\mathrm{H}_{2} \mathrm{O}}$ & $\begin{array}{l}\text { Soil Temperature } \\
-10 \mathrm{~cm}\left({ }^{\circ} \mathrm{C}\right)\end{array}$ & $\begin{array}{l}\text { Soil Water Content } \\
-10 \mathrm{~cm}\left(\mathrm{~m}^{3} \mathrm{~m}^{-3}\right)\end{array}$ \\
\hline B1 & $\begin{array}{l}\text { N } 58^{\circ} 18^{\prime} 24.8 \\
\text { E } 27^{\circ} 15^{\prime} 23.1\end{array}$ & $222 \pm 33$ & $43 \pm 2$ & $4.38 \pm 0.05$ & $11.76 \pm 0.04$ & $0.21 \pm 0.02$ \\
\hline B2 & $\begin{array}{c}\text { N } 58^{\circ} 17^{\prime} 21.4 \\
\text { E } 27^{\circ} 19^{\prime} 3.2\end{array}$ & $206 \pm 50$ & $87 \pm 1$ & $5.68 \pm 0.05$ & $12.00 \pm 0.21$ & $0.23 \pm 0.03$ \\
\hline B3 & $\begin{array}{l}\text { N } 58^{\circ} 18^{\prime} 37.0 \\
\text { E } 27^{\circ} 21^{\prime} 11.8\end{array}$ & $251 \pm 25$ & $77 \pm 3$ & $4.85 \pm 0.03$ & $11.86 \pm 0.08$ & $0.30 \pm 0.06$ \\
\hline \multicolumn{2}{|c|}{ Means for birch } & $226 \pm 20$ & $69 \pm 6$ & $4.97 \pm 0.16$ & $11.87 \pm 0.07$ & $0.25 \pm 0.03$ \\
\hline S1 & $\begin{array}{l}\text { N } 58^{\circ} 18^{\prime} 6.3 \\
\text { E } 27^{\circ} 16^{\prime} 54.0\end{array}$ & $242 \pm 40$ & $49 \pm 2$ & $5.08 \pm 0.13$ & $11.68 \pm 0.18$ & $0.32 \pm 0.03$ \\
\hline S2 & $\begin{array}{l}\text { N } 58^{\circ} 17^{\prime} 49.3 \\
\text { E } 27^{\circ} 14^{\prime} 53.4\end{array}$ & $289 \pm 71$ & $36 \pm 5$ & $4.93 \pm 0.30$ & $10.76 \pm 0.10$ & $0.24 \pm 0.03$ \\
\hline S3 & $\begin{array}{l}\text { N } 58^{\circ} 15^{\prime} 14.5 \\
\text { E } 27^{\circ} 17^{\prime} 44.2\end{array}$ & $140 \pm 42$ & $65 \pm 6$ & $4.04 \pm 0.05$ & $11.23 \pm 0.07$ & $0.19 \pm 0.02$ \\
\hline \multicolumn{2}{|c|}{ Means for spruce } & $217 \pm 33$ & $51 \pm 4$ & $4.63 \pm 0.16$ & $11.23 \pm 0.12$ & $0.25 \pm 0.02$ \\
\hline
\end{tabular}

\subsection{Collection of Root Samples and Preparation}

Root sampling from three birch and three spruce stands in the Järvselja forest area were carried out in September-October 2018. We collected five root samples per sampling plot at distances of $5,15,40$, and $80 \mathrm{~m}$ from the ditch with a spade from the $20 \mathrm{~cm}$ deep topsoil layers at random locations. A total of 125 root samples were collected from all six stands, packed in plastic bags, transported to the lab, and stored at $4{ }^{\circ} \mathrm{C}$ until further processing in the lab. In the lab, five to six approximately $10 \mathrm{~cm}$ long fine root segments 
of birch and spruce were removed from each root sample. Tree fine roots were separated from the fine roots of understory vegetation visually according to their morphology and color. Fine root segments of each sample were washed free of soil particles, kept with water in plastic containers, and stored in the freezer $\left(-18^{\circ} \mathrm{C}\right)$ until further absorptive root morphological analysis.

Table 2. Means \pm standard errors of the stand characteristics of four sampling plots per stand (B1-B3, birch stands; S1-S3, spruce stands) and of the three replicate stands per sampling plot at the distances of 5, 15, 40, and $80 \mathrm{~m}$ from the ditch. BA—-basal area; DBH-diameter at breast height. Small letters show a statistically significant difference (one-way ANOVA, followed by Tukey's HSD; $p<0.05$ ) of the mean stand characteristics among three birch and three spruce stands, and also among four distances from the ditch.

\begin{tabular}{|c|c|c|c|c|c|}
\hline $\begin{array}{c}\text { Stand } \\
\text { Characteristics }\end{array}$ & Species & Replicate Stands & $\begin{array}{l}\text { Stand Values } \\
\text { (Per Stand) }\end{array}$ & $\begin{array}{l}\text { Distances from } \\
\text { the Ditch (m) }\end{array}$ & $\begin{array}{c}\text { Stand Values } \\
\text { (Per Sampling Plot) }\end{array}$ \\
\hline \multirow{8}{*}{$\begin{array}{l}\text { Stand density } \\
\left(\text { trees } \mathrm{ha}^{-1}\right)\end{array}$} & \multirow{4}{*}{ Birch } & B1 & $2000 \pm 294$ & 5 & $1400 \pm 0$ \\
\hline & & $\mathrm{B} 2$ & $2100 \pm 268$ & 15 & $1633 \pm 260$ \\
\hline & & B3 & $1325 \pm 229$ & 40 & $1867 \pm 546$ \\
\hline & & & & 80 & $2333 \pm 233$ \\
\hline & \multirow{4}{*}{ Spruce } & S1 & $1075 \pm 138^{b}$ & 5 & $1200 \pm 178$ \\
\hline & & $\mathrm{S} 2$ & $1900 \pm 183^{a}$ & 15 & $1600 \pm 289$ \\
\hline & & S3 & $1340 \pm 169 \mathrm{ab}$ & 40 & $1433 \pm 376$ \\
\hline & & & & 80 & $1550 \pm 150$ \\
\hline \multirow{8}{*}{$\mathrm{BA}\left(\mathrm{m}^{2} \mathrm{ha}^{-1}\right)$} & \multirow{4}{*}{ Birch } & B1 & $25 \pm 4$ & 5 & $24 \pm 1$ \\
\hline & & B2 & $20 \pm 3$ & 15 & $23 \pm 5$ \\
\hline & & B3 & $18 \pm 3$ & 40 & $21 \pm 6$ \\
\hline & & & & 80 & $16 \pm 1$ \\
\hline & \multirow{4}{*}{ Spruce } & S1 & $32 \pm 6$ & 5 & $30 \pm 7$ \\
\hline & & $\mathrm{S} 2$ & $28 \pm 4$ & 15 & $29 \pm 3$ \\
\hline & & S3 & $22 \pm 1$ & 40 & $20 \pm 2$ \\
\hline & & & & 80 & $25 \pm 4$ \\
\hline \multirow{8}{*}{$\mathrm{DBH}(\mathrm{cm})$} & \multirow{4}{*}{ Birch } & B1 & $15 \pm 2$ & 5 & $15 \pm 0^{a}$ \\
\hline & & $\mathrm{B} 2$ & $14 \pm 1$ & 15 & $16 \pm 2^{a}$ \\
\hline & & B3 & $14 \pm 1$ & 40 & $16 \pm 1^{a}$ \\
\hline & & & & 80 & $11 \pm 0^{b}$ \\
\hline & \multirow{4}{*}{ Spruce } & $\mathrm{S} 1$ & $20 \pm 1$ & 5 & $19 \pm 1$ \\
\hline & & $\mathrm{S} 2$ & $17 \pm 1$ & 15 & $17 \pm 2$ \\
\hline & & $\mathrm{S} 3$ & $16 \pm 2$ & 40 & $16 \pm 2$ \\
\hline & & & & 80 & $17 \pm 0$ \\
\hline
\end{tabular}

\subsection{Absorptive Root Morphology}

First- and second-order roots, defined as absorptive roots [13,14], were assessed in this study. Four random subsamples were created from fine root segments of a sample. Absorptive roots of each subsample (about 20-40 tips) were randomly taken from fine root segments and counted under the microscope. Subsequently, absorptive roots were cleaned with a small soft brush to remove all soil and organic debris. The total number of absorptive roots sampled and analyzed per stand ranged from 2026 to 2335 and from 2054 to 2546 in birch and spruce stands, respectively. Absorptive roots of each subsample were placed in a transparent water-filled tray with minimum overlap and scanned. The length $(\mathrm{L}, \mathrm{cm})$, surface area $\left(\mathrm{SA}, \mathrm{cm}^{2}\right)$, and volume $\left(\mathrm{V}, \mathrm{cm}^{3}\right)$ of a sample and the mean absorptive root diameter $(\mathrm{D}, \mathrm{mm})$ were directly measured by the WinRHIZO ${ }^{\mathrm{TM}}$ Pro $2003 \mathrm{~b}$ image analysis system (Regent Instruments Inc., Chemin Sainte-Foy, QC, Canada). The absorptive roots of each subsample were oven-dried at $65^{\circ} \mathrm{C}$ for $4 \mathrm{~h}$ to constant weight and weighed to $0.05 \mathrm{mg}$ accuracy. All root morphological parameters were calculated on the subsample level. The mean absorptive root length $(\mathrm{L}, \mathrm{mm})$ and dry weight $(\mathrm{W}, \mathrm{mg})$ were 
calculated by dividing the length and dry weight of the absorptive roots by the number of absorptive roots in a subsample, respectively. Specific root area (SRA, $\mathrm{m}^{2} \mathrm{~kg}^{-1}$ ) was calculated as the surface area divided by the dry weight of absorptive roots. Specific root length (SRL, $\mathrm{m} \mathrm{g}^{-1}$ ) was calculated as the absorptive root length divided by the dry weight of absorptive roots. Root tissue density (RTD, $\mathrm{kg} \mathrm{m}^{-3}$ ) was calculated as the dry weight divided by the calculated volume of the absorptive roots [15]. Branching intensity was expressed as the number of absorptive roots per unit of length $\left(\mathrm{BI}_{\mathrm{L}}, \mathrm{cm}^{-1}\right)$ and per unit of dry weight $\left(\mathrm{BI}_{\mathrm{w}}, \mathrm{mg}^{-1}\right)[33,40]$.

\subsection{Data Analyses}

Statistical analyses were carried out using the STATISTICA 7.1 software (StatSoft Inc., Tulsa, OK, USA). In all cases, a level of statistical significance of $p<0.05$ was accepted. The normality of the variable distribution was verified using the Shapiro-Wilk and Kolmogorov-Smirnov tests. A one-way analysis of variance (ANOVA), followed by Tukey's HSD, was performed to test the differences of absorptive root morphological traits, stand and soil characteristics between sampling plots, replicate stands, and tree species. The multiple stepwise regression analysis was applied to determine which soil and root-related properties significantly influenced absorptive root morphology in birch and spruce. For this aim, three groups of soil factors were examined: (1) soil temperature, soil water content, peat depth, and soil $\mathrm{pH}_{\mathrm{H} 2 \mathrm{O}}$; (2) soil chemical factors ( $\mathrm{C} / \mathrm{N}$ ratio, $\mathrm{DOC}, \mathrm{N}, \mathrm{K}, \mathrm{P}, \mathrm{Ca}$, and $\mathrm{S}$ ); and (3) tree-related factors (FRB, FRB per stand BA $\left(\mathrm{kg} \mathrm{m}^{-2}\right)$, fine root turnover $\left(\mathrm{yr}^{-1}\right)$, and ratio of tree/understory root biomass). A linear regression analysis was further used to determine the relationship between absorptive root morphological traits and the significant factors of the stand and soil characteristics within birch and spruce. A correlation matrix (Pearson's r; $p<0.05$ ) was constructed to observe the correlations between the stand and soil characteristics, as well as between absorptive root morphological traits and stand and soil properties. A type III general linear model (GLM) was used to assess the impacts of the forest stand and distance from the ditch $(\mathrm{m})$ on absorptive root morphological traits in birch and spruce. Redundancy analysis (RDA) (CANOCO program; ter Braak and Smilauer, 2002) was used to describe the relationships between absorptive root morphological traits, tree species, forest stands, sampling plots, stands, and soil characteristics.

\section{Results}

\subsection{Stand and Soil Characteristics}

The average stand density and BA were similar between birch and spruce stands (Table 2). The mean DBH was significantly smaller in birch than spruce stands $(p<0.01$, Table 2). The seasonal variation in mean soil VWC was comparable between birch and spruce stands (Figure S3A,B). Among the spruce stands, the stand density in S2 was significantly higher than that in S1 $(p<0.01$, Table 2), while the stand density in S3 was similar to those in S1 and S2 (Table 2).

Among the studied sampling plots, the mean $\mathrm{DBH}$ in birch stands at plot 80 was significantly lower than those in the rest of the sampling plots $(p<0.05$, Table 2$)$. Spruce fine root biomass per stand basal area (FRB/BA) tended to be lower in plots close to the ditch and increased significantly between plot 15 and plot $40\left(49 \pm 5\right.$ and $119 \pm 8 \mathrm{~kg} \mathrm{~m}^{-2}$, respectively, $p<0.05$, Figure $1 \mathrm{~B})$. FRB in spruce was positively related to BA ( $\mathrm{r}=0.60$; $p<0.05$, Figure S4). Soil VWC was similar along with distances from the ditch in all stands in 2015 (Figure S1A-F). The exception was S1, where the mean soil VWC was significantly lower at plot 40 than plot $5(p<0.001$, Figure S1D). However, in B2, the mean soil VWC was significantly greater at plot 40 than plot 5 measured in $2018(0.41 \pm 0.09$ and $0.19 \pm 0.04 \mathrm{~m}^{3} \mathrm{~m}^{-3}$, respectively, $\left.p<0.05\right)$. The seasonal variation in mean soil VWC in the studied stands in 2015 and 2018 was similar, especially during September-October (Figure S2). There was no significant relationship between the precipitation and soil VWC in 2015 and 2018 (Figure S2). The mean soil temperature was also similar between sampling 
plots of the stands during April-October 2018, ranging from $8.9 \pm 2.0$ to $16.6 \pm 1.8^{\circ} \mathrm{C}$ between $\mathrm{S} 1$ at plot 5 and $\mathrm{B} 2$ at plot 5 , respectively.

A

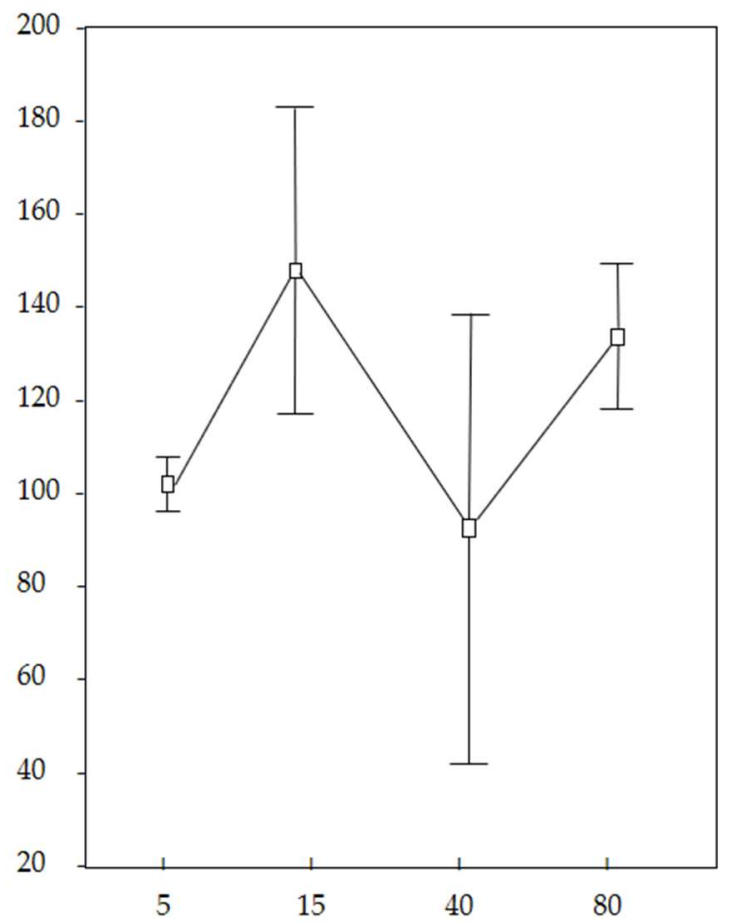

B

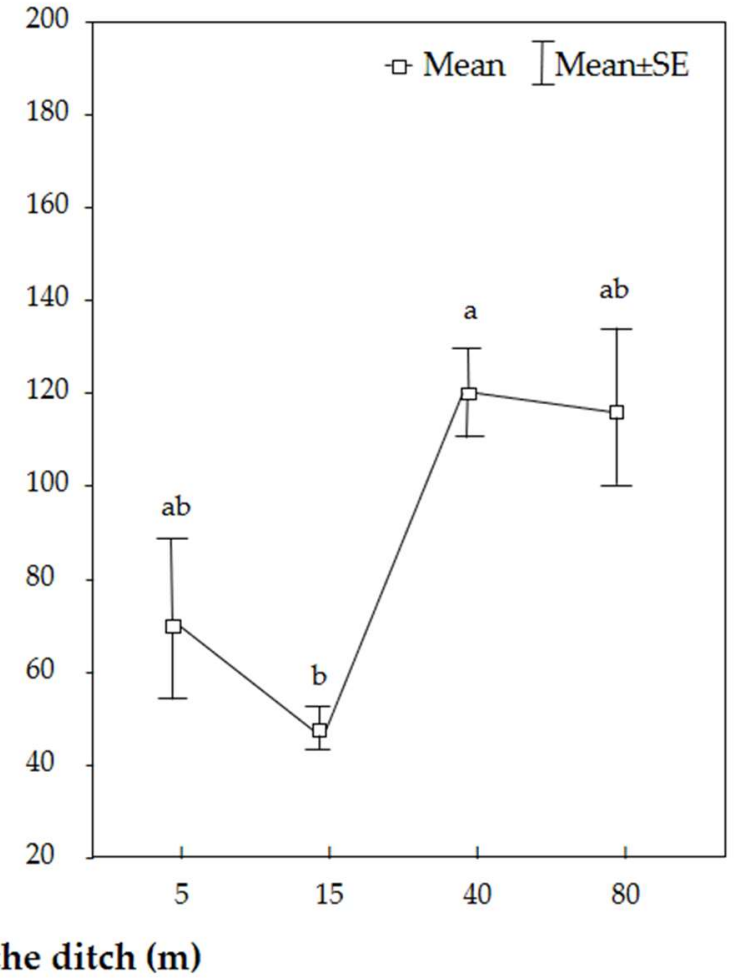

Figure 1. Means of the fine root biomass per stand basal area (FRB/BA, $\mathrm{kg} \mathrm{m}^{-2}$ ) with the standard error bars of three replicate stands per sampling plot at the distances of 5, 15, 40, and $80 \mathrm{~m}$ from the ditch in Downy birch (A) and Norway spruce (B). Small letters indicate a statistically significant difference (one-way ANOVA, followed by Tukey's HSD; $p<0.05$ ) of the mean spruce FRB/BA between four sampling plots.

\subsection{Variation in Absorptive Root Morphology across Tree Species and Distance from the Ditch}

Absorptive root morphology was significantly different between birch and spruce (Table 3). The absorptive roots of birch tended to be thinner $(0.227 \pm 0.002$ vs. $0.274 \pm 0.003 \mathrm{~mm})$, shorter $(1.14 \pm 0.05$ vs. $1.84 \pm 0.02 \mathrm{~mm})$, and have a lower RTD $\left(258 \pm 5 \mathrm{vs.} 293 \pm 6 \mathrm{~kg} \mathrm{~m}^{-3}\right)$ than spruce. The mean absorptive root $\mathrm{W}$ was 2.6 times lower in birch than spruce (Table 3 ). The mean absorptive root SRA and SRL were higher for birch than spruce (Tables 3 and S1). Similarly, $\mathrm{BI}_{\mathrm{L}}$ and $\mathrm{BI}_{\mathrm{W}}$ were higher in birch than spruce (Tables 3 and $\mathrm{S} 1$ ).

Along the distance gradient from the ditch, the mean SRA increased significantly toward plot 80 in birch and spruce (Table 3). The mean SRL of birch increased significantly from plot 15 to 80 , while the mean SRL of spruce was higher at plot 15 than 5 (Table 3). The mean RTD decreased significantly with distance from the ditch (from plot 5 to plot 80) in birch and spruce stands (from $262 \pm 11$ to $242 \pm 10 \mathrm{~kg} \mathrm{~m}^{-3}$ and from $295 \pm 6$ to $276 \pm 1 \mathrm{~kg} \mathrm{~m}^{-3}$, respectively, Table 3). The mean absorptive root $\mathrm{D}$ of birch was similar between four sampling plots, while it varied between plot 15 and plot 80 in spruce stands (Table 3). A significant decrease in the mean $\mathrm{L}$ and $\mathrm{W}$ of the absorptive root of birch was found from plot 15 to plot 40 . The mean absorptive root $\mathrm{L}$ of spruce was comparable between four sampling plots, while the mean $\mathrm{W}$ varied significantly between plot 5 and plot 15 (Table 3). 
Table 3. Means \pm standard errors of absorptive root morphological traits of the three replicate stands per sampling plot at the distances of 5, 15, 40, and $80 \mathrm{~m}$ from the ditch and of the four sampling plots per birch and spruce. D—diameter $(\mathrm{mm}), \mathrm{L}$-length $(\mathrm{mm}), \mathrm{W}$-dry weight $(\mathrm{mg}), \mathrm{BI}_{\mathrm{L}}$ - branching intensity per length $\left(\mathrm{cm}^{-1}\right), \mathrm{BI}_{\mathrm{w}}$ - branching intensity per mass $\left(\mathrm{mg}^{-1}\right)$, SRA—specific root area $\left(\mathrm{m}^{2} \mathrm{~kg}^{-1}\right)$, SRL—specific root length $\left(\mathrm{m} \mathrm{g}^{-1}\right)$, and RTD—root tissue density $\left(\mathrm{kg} \mathrm{m}^{-3}\right)$. Small letters indicate a statistically significant difference (one-way ANOVA, followed by Tukey's HSD; $p<0.05$ ) of the mean absorptive root morphological traits between four sampling plots within birch and spruce. Capital letters denote a statistically significant difference (one-way ANOVA, followed by Tukey's HSD; $p<0.05$ ) of the mean absorptive root morphological traits of four sampling plots between birch and spruce.

\begin{tabular}{|c|c|c|c|c|c|c|}
\hline \multirow[b]{2}{*}{ Root Traits } & \multicolumn{5}{|c|}{ Distances from the Ditch (m) } & \multirow[b]{2}{*}{$\begin{array}{l}\text { Means of Four } \\
\text { Sampling Plots }\end{array}$} \\
\hline & Stands & 5 & 15 & 40 & 80 & \\
\hline \multirow{2}{*}{$\mathrm{D}(\mathrm{mm})$} & Birch & $0.227 \pm 0.013$ & $0.231 \pm 0.012$ & $0.221 \pm 0.003$ & $0.229 \pm 0.011$ & $0.227 \pm 0.002^{\mathrm{B}}$ \\
\hline & Spruce & $0.278 \pm 0.007^{a b}$ & $0.265 \pm 0.004^{c}$ & $0.272 \pm 0.005^{a b c}$ & $0.281 \pm 0.009 \mathrm{ab}$ & $0.274 \pm 0.003^{\mathrm{A}}$ \\
\hline \multirow{2}{*}{$\mathrm{L}(\mathrm{mm})$} & Birch & $1.12 \pm 0.14^{a b c}$ & $1.27 \pm 0.09^{\mathrm{a}}$ & $1.01 \pm 0.19^{c}$ & $1.16 \pm 0.13^{a b c}$ & $1.14 \pm 0.05^{\text {B }}$ \\
\hline & Spruce & $1.90 \pm 0.06$ & $1.82 \pm 0.07$ & $1.86 \pm 0.07$ & $1.78 \pm 0.02$ & $1.84 \pm 0.02^{\mathrm{A}}$ \\
\hline \multirow{2}{*}{$\mathrm{W}(\mathrm{mg})$} & Birch & $0.0124 \pm 0.0035^{a b c}$ & $0.0141 \pm 0.0026^{a}$ & $0.0105 \pm 0.0025^{c}$ & $0.0123 \pm 0.0027^{a b c}$ & $0.0124 \pm 0.0007^{\mathrm{B}}$ \\
\hline & Spruce & $0.0339 \pm 0.0021^{\mathrm{a}}$ & $0.0301 \pm 0.0012^{c}$ & $0.0324 \pm 0.0020^{\mathrm{abc}}$ & $0.0305 \pm 0.0016^{\mathrm{abc}}$ & $0.0317 \pm 0.0009^{\mathrm{A}}$ \\
\hline \multirow{2}{*}{$\mathrm{BI}_{\mathrm{L}}\left(\mathrm{cm}^{-1}\right)$} & Birch & $9.58 \pm 1.10^{b c}$ & $8.45 \pm 0.67^{b c}$ & $11.26 \pm 1.90^{\mathrm{a}}$ & $9.40 \pm 1.15^{b c}$ & $9.67 \pm 0.58^{\mathrm{A}}$ \\
\hline & Spruce & $5.44 \pm 0.12$ & $5.60 \pm 0.23$ & $5.53 \pm 0.23$ & $5.73 \pm 0.03$ & $5.58 \pm 0.06^{\mathrm{B}}$ \\
\hline \multirow{2}{*}{$\mathrm{BI}_{\mathrm{W}}\left(\mathrm{mg}^{-1}\right)$} & Birch & $99.0 \pm 22.9 \mathrm{abc}$ & $82.2 \pm 15.4^{c}$ & $121.4 \pm 24.6^{a b}$ & $106.3 \pm 26.8^{a b}$ & $102.2 \pm 8.1^{\mathrm{A}}$ \\
\hline & Spruce & $31.1 \pm 1.6^{c}$ & $34.3 \pm 1.4^{\mathrm{a}}$ & $32.5 \pm 2.3^{a b c}$ & $34.6 \pm 1.6^{\mathrm{abc}}$ & $33.1 \pm 0.8^{\mathrm{B}}$ \\
\hline \multirow{2}{*}{$\operatorname{SRA}\left(\mathrm{m}^{2} \mathrm{~kg}^{-1}\right)$} & Birch & $69 \pm 6^{\mathrm{abc}}$ & $68 \pm 4^{c}$ & $71 \pm 4^{\mathrm{abc}}$ & $75 \pm 6^{a}$ & $71 \pm 2^{\mathrm{A}}$ \\
\hline & Spruce & $50 \pm 1^{b c}$ & $51 \pm 1^{\mathrm{abc}}$ & $50 \pm 1^{b c}$ & $53 \pm 2^{a}$ & $51 \pm 1^{\mathrm{B}}$ \\
\hline \multirow{2}{*}{$\operatorname{SRL}\left(\mathrm{m} \mathrm{g}^{-1}\right)$} & Birch & $100 \pm 14^{\mathrm{abc}}$ & $95 \pm 11^{c}$ & $105 \pm 4^{a b c}$ & $108 \pm 14^{a}$ & $103 \pm 3^{A}$ \\
\hline & Spruce & $57 \pm 2^{c}$ & $62 \pm 1^{a}$ & $59 \pm 2^{a b c}$ & $60 \pm 3^{a b c}$ & $59 \pm 1^{\mathrm{B}}$ \\
\hline \multirow{2}{*}{$\operatorname{RTD}\left(\mathrm{kg} \mathrm{m}^{-3}\right)$} & Birch & $262 \pm 11^{\mathrm{ab}}$ & $262 \pm 4^{\mathrm{ab}}$ & $264 \pm 17^{a b}$ & $242 \pm 10^{c}$ & $258 \pm 5^{B}$ \\
\hline & Spruce & $295 \pm 6^{a b}$ & $300 \pm 7^{a b}$ & $300 \pm 4^{\mathrm{ab}}$ & $276 \pm 1^{c}$ & $293 \pm 6^{\mathrm{A}}$ \\
\hline
\end{tabular}

\subsection{Relationships between Absorptive Root Morphology and the Characteristics of Soil and Stands}

Multiple stepwise regression analysis revealed that the mean RTD had a significant negative relationship with peat depth among birch stands; the mean RTD was higher at the stand with a thinner peat layer (Figure 2A). In spruce, the mean absorptive root D had a positive relationship with soil $\mathrm{pH}$, while RTD was negatively related to soil $\mathrm{pH}$ (Figure $2 \mathrm{~B}, \mathrm{C}$ ). The mean absorptive root $\mathrm{D}$ also showed a positive relationship with $\mathrm{FRB}$ $\left(\mathrm{R}^{2}=0.43, p<0.05\right)$, while RTD was negatively related to FRB $\left(\mathrm{R}^{2}=0.38, p<0.05\right)$. Among the studied soil chemical factors, RTD in spruce was related to soil C/N, $\mathrm{P}$, and Ca $\left(\mathrm{R}^{2}=0.89\right.$, $p<0.05)$. The mean absorptive root $\mathrm{BI}_{\mathrm{w}}$ in spruce showed a significant relationship with soil temperature, with fewer branched absorptive roots toward warmer soils (Figure 2D).

According to Pearson's correlation analyses, the peat depth in birch stands had a positive correlation with soil $\mathrm{pH}(\mathrm{r}=0.87 ; p<0.001)$ and Ca concentration $(\mathrm{r}=0.87$; $p<0.001$ ) (Table S2). Soil $\mathrm{pH}$ in spruce stands was negatively correlated with peat depth $(\mathrm{r}=-0.70 ; p<0.01)$ and $\mathrm{C} / \mathrm{N}$ ratio $(\mathrm{r}=-0.077 ; p<0.01)$, while it was positively correlated with soil Ca concentration $(\mathrm{r}=0.69 ; p<0.01)$ (Table $\mathrm{S} 2)$.

The general linear model (GLM) showed that forest stands had a significant effect on the variation in absorptive root morphological traits such as $\mathrm{L}, \mathrm{BI}_{\mathrm{L}}$, and $\mathrm{RTD}$ only in birch. Distance from the ditch also influenced the mean RTD in birch (Table S3). 
A
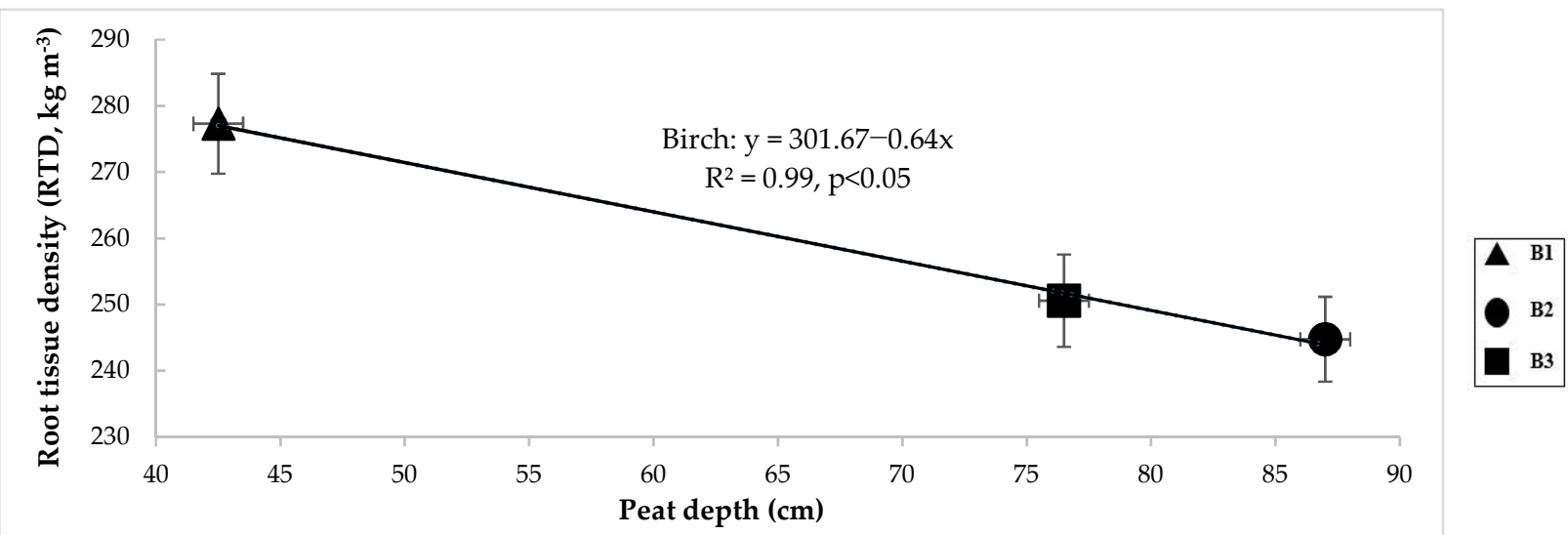

B
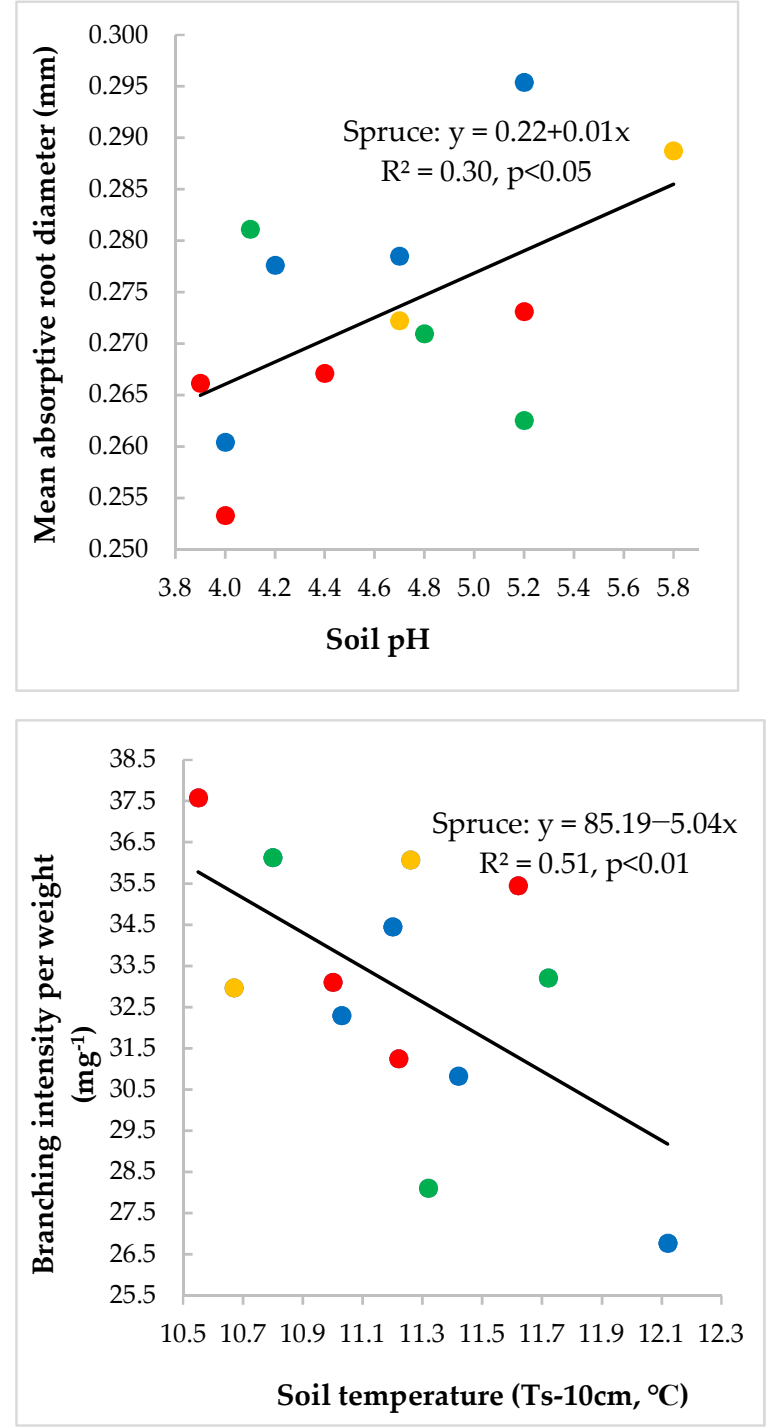

C

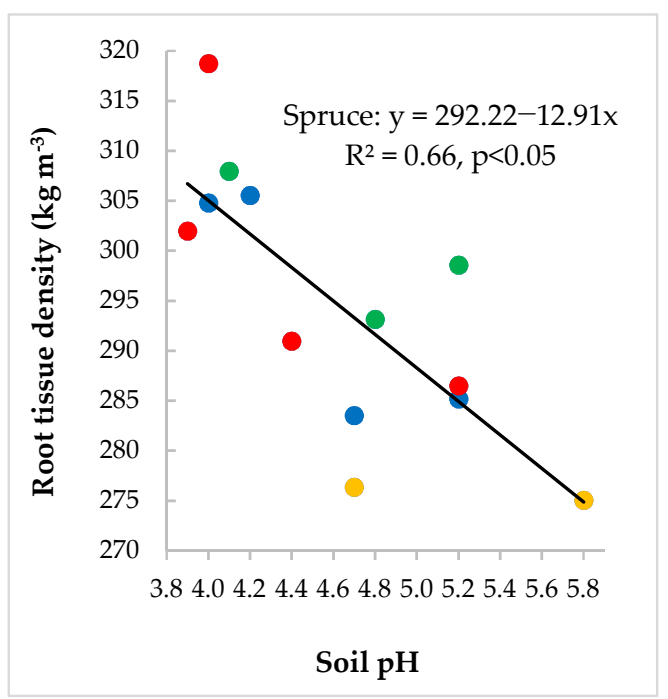

$\bullet$ Plot 5

$\bullet$ Plot 15

- Plot 40

- Plot 80

Figure 2. Relationships between absorptive root morphological traits of studied stands in birch (A) and all sampling plots (5, 15, 40, and 80) in spruce with the soil characteristics (B-D). The soil temperature was measured from a depth of $10 \mathrm{~cm}$.

Based on RDA forward selection analysis, a total of $65.4 \%$ of the variation in absorptive root morphological traits was explained by tree species, B1 and S2 stands, sampling plots lo- 
cated $15 \mathrm{~m}$ and $80 \mathrm{~m}$ from the ditch, and stand density, BA, FRB, soil $\mathrm{N}$ and P concentration, and soil water content ( $p<0.05$, Figure $3 \mathrm{~A}$ ). The first axis described $63.2 \%$ of the root trait variation, which was strongly related to the variations in $\mathrm{BI}_{\mathrm{W}}, \mathrm{SRA}, \mathrm{W}$, and $\mathrm{L}$ of absorptive roots depending on the tree species (Figure 3A). RTD was weakly related to the second axis of the biplot that explained only about $1.5 \%$ of the root trait variation and indicated a lower value of RTD toward a $80 \mathrm{~m}$ distance from the ditch (Figure 3A). However, when analyzed separately by species, the $\mathrm{BI}_{\mathrm{W}}$ and root tip mass were most strongly related to the first axis and explained significantly by soil $\mathrm{C} / \mathrm{N}$ ratio and $\mathrm{Ca}$ concentration in birch (Figure 3B) and soil temperature in spruce (Figure 3C). A significant relationship between turnover rates and absorptive root diameter was depicted in both tree species; thicker roots revealed higher turnover rates (Figure 3B,C).

A

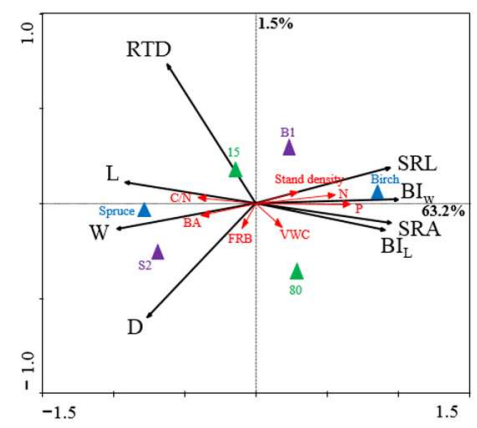

B

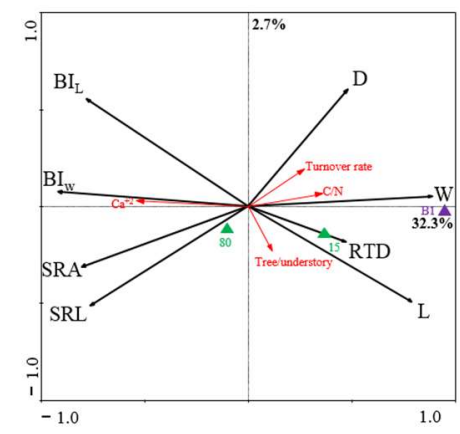

C

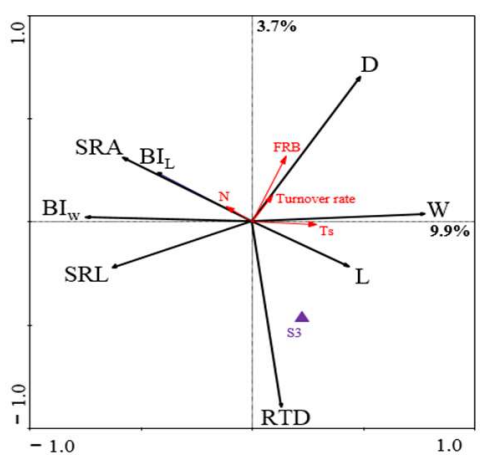

Figure 3. The ordination biplot based on redundancy analysis (RDA, manual forward selection) of absorptive root morphological traits, including D-diameter $(\mathrm{mm}), \mathrm{L}$-length $(\mathrm{mm}), \mathrm{W}$-dry weight $(\mathrm{mg}), \mathrm{BI}_{\mathrm{L}}$-branching intensity per length $\left(\mathrm{cm}^{-1}\right), \mathrm{BI}_{\mathrm{W}}$ - branching intensity per mass $\left(\mathrm{mg}^{-1}\right)$, SRA—specific root area $\left(\mathrm{m}^{2} \mathrm{~kg}^{-1}\right)$, SRL—specific root length $\left(\mathrm{m} \mathrm{g}^{-1}\right)$, and RTD—root tissue density $\left(\mathrm{kg} \mathrm{m}^{-3}\right)$ (black arrows) for both studied tree species, Downy birch and Norway spruce (A), and separately for birch (B) and spruce (C). In all figures, absorptive root morphological traits were shown in relation to the tree species (blue triangles), forest stands (purple triangles), sampling plots (green triangles), and studied stand and soil characteristics (red arrows). The relative eigenvalues of axis 1 and axis 2 were $63.2 \%$ and $1.5 \%$, respectively, and in total, the model described $65.4 \%$ of the variation in absorptive root traits (Figure $3 \mathrm{~A}, p<0.05$ ).

\section{Discussion}

\subsection{Absorptive Root Morphological Variation in the Tree Species at Drained Peat Soils}

Absorptive roots exhibit several morphological traits that determine the plant's resource uptake strategies and mediate plant feedback to ecosystem functioning $[17,24]$. However, the morphology of absorptive roots of different tree species in hemiboreal peatland forests with organic soils has been poorly characterized.

We observed that the considerable variation in the absorptive root morphological traits is linked to the different tree species (i.e., deciduous vs. coniferous). The absorptive roots of birch were thinner and had a lower RTD; thus, their SRA and SRL were 1.4 and 1.7 times higher than those of spruce, respectively. Our results observed from the drained peat soils are congruent with an earlier study performed at the alkaline soils, which showed that the absorptive root SRA and SRL of deciduous trees (black alder and silver birch) were 1.5-2.5 times higher than those of conifer (Scots pine) tree species [18]. Species with contrasting root morphology may exhibit different nutrient foraging strategies [41,42]. Compared to the deciduous trees, evergreen conifers typically exhibit thicker roots and lower SRL for soil resource acquisition [43]. Root branching intensity per length and mass unit was also influenced by tree species identity, being 2 and 3 times higher in birch than spruce, respectively, aligning with previous studies [33,40]. 
However, the mean SRA and SRL of birch at drained peat soils were lower than the same values of deciduous trees at alkaline soils, while the mean SRA and SRL of spruce were of the same order of magnitude as those reported for conifer at the alkaline soils [18]. The mean root $\mathrm{BI}_{\mathrm{L}}$ of birch and spruce at drained peat soils was identical to those reported for deciduous broadleaved $\left(5.4-9.6 \mathrm{~cm}^{-1}\right)$ but higher compared to coniferous species $\left(3.3 \mathrm{~cm}^{-1}\right)$ under mesic mesotrophic site conditions, respectively [33]. Differences in species identity and studied soil type can also account for the conflicting results mentioned above.

\subsection{Absorptive Root Morphological Variation along with the Distance from the Ditch}

Even though the morphology of the absorptive roots varied substantially among tree species, the response patterns of some root traits, such as SRA and RTD, to distance gradient from the ditch were directionally consistent for tree species. This is in agreement with our first hypothesis, suggesting that the effect of distance from the ditch on morphological variations of absorptive roots is similar between birch and spruce. The mean SRL also varied with distance gradient from the ditch, but it was only evident in birch. Similar to our result, Werger et al. [44] showed that the effect of wind intensity on the fine root morphological traits, such as SRA, SRL, and RTD, was uniform in all grassland species. However, our results contradict previously reported species-specific root morphological responses to adverse soil conditions [23,45].

Absorptive roots are functionally important for the acquisition of soil resources and are highly plastic to changes in soil properties [46]. In line with our second hypothesis, we found that the mean SRA increased while RTD decreased with distance from the ditch. This finding highlights the morphological adjustment of absorptive roots to the local soil properties at different distances from the ditch and possibly a shift in nutrient foraging. However, in our study, the soil physical and chemical properties were not dependent on the distance from the ditch. This result is in contradiction with previous studies that found that at spatially higher distances from the ditch, soil properties are becoming poor $[6,8]$. For instance, the aeration of the substrate, decomposition of organic matter, and nutrient availability reduced, which were attributed to the higher water table level at sites located far away from the ditch [6]. In the present study, we observed a statistically similar soil water content along with distances from the ditch, but water content tended to be higher toward plots far away from the ditch, ranging from $0.22 \mathrm{~m}^{3} \mathrm{~m}^{-3}$ at plot 5 to $0.27 \mathrm{~m}^{3} \mathrm{~m}^{-3}$ at plot 80 in the studied stands. On the other hand, many studies reported that the soil microclimate and hydrology of peat soils can be noticeably influenced by other factors than ditch distance, for example, topography, vegetation characteristics, tree stands, climatic conditions, as well as peat and subsoil hydraulic properties [47-49]. It will therefore be important to explore those effects to better determine soil moisture at peatland forests.

An increase in SRA and a decrease in RTD toward higher distances from the ditch observed in this study can support the more efficient acquisition of soil resources. Indeed, strategies that increase the absorptive surface area per unit mass are thought to be more effective at increasing the potential of a root system to uptake resources [28]. Moreover, we found that at drained spruce peatland forests, FRB per stand BA tended to be lower at sites close to the ditch, and this could probably reflect more advanced root foraging near the ditch than farther distances, as fewer roots in the belowground supported the same basal area unit in the aboveground at sites close to the ditch.

The soil microbial communities are essential drivers in the mineralization of organic matter and mediate soil nutrient cycling [50]. Previous studies showed shifts in the soil bacterial and fungal communities with distance gradient from the ditch $[9,51]$. For example, Qiu et al. [52] revealed that fungal diversity was higher at a plot $5 \mathrm{~m}$ from the ditch related to the well-drained soil condition and the improvements in nutrient availability compared to the plot at a $75 \mathrm{~m}$ distance with poor drainage condition. Therefore, changes in fungal community structures in peat soil might serve as a sensitive indicator for changes in soil properties. Given also the complementarity between absorptive roots and associated mycorrhizal fungi in nutrient foraging, further investigation should pay attention to both 
root and root-associated-fungi traits to better identify tree growth responses and peatland forest functioning.

\subsection{Absorptive Root Morphological Variation with the Stand and Soil Properties}

Here, the absorptive root morphology was substantially influenced by the soil physical and chemical properties, including peat depth, $\mathrm{pH}$, and temperature. However, all of these soil factors were similar along with distances from the ditch. The two examined tree species growing at similar drained histosols showed different responses in their absorptive root morphological traits to the local soil properties. Correspondingly, several studies revealed that the response of the absorptive root morphological traits to the soil conditions varies across plant species $[18,23]$. Similarly, we found that absorptive root morphology varied between stands of the same forest type, but such variations differed between birch and spruce. For example, forest stands affected the variations in absorptive root morphological traits such as $\mathrm{L}, \mathrm{BI}_{\mathrm{L}}$, and RTD only in birch. The mean RTD in the three birch stands was negatively related to the peat depth, which varied from 43 to $57 \mathrm{~cm}$ between B1 and B2, respectively. Among all studied spruce stands, soil $\mathrm{pH}$ was the main soil factor affecting absorptive root morphological variation. Mean absorptive root D was lowest, while RTD was highest in the most acidic spruce forest soils $(\mathrm{pH}=3.8-4.0)$. Similar to our findings, the significant negative relationships between RTD and soil $\mathrm{pH}$ were shown previously $[53,54]$. In addition, in this study, soil $\mathrm{pH}$ was negatively correlated with peat depth in spruce stands. This suggests that at more acidic soils with thicker peat depths, the decomposition rate and available nutrients were probably lower. Therefore, producing thinner roots with low RTD at acidic soils in spruce stands could support the more resource acquisition strategy. Doi et al. [20] also showed the production of thinner second-order roots at more acidic soils, attributed to the higher nutrient absorption efficiency.

Soil temperature ranged from 10.6 to $12.1^{\circ} \mathrm{C}$ at spruce forests. Root branching intensity (per mass unit) exhibited a high sensitivity following the soil temperature range at drained peat soils of spruce stands. Decreased soil temperature significantly increased the root branching intensity of spruce, consistent with previous research in spruce stands [55]. In a recent analysis of root traits, Liese et al. [33] showed that the root BI is a key trait determining the root plastic responses to a changing environment. Low soil temperature influenced nutrient availability by low mineralization rates [56]. The high branching intensity of the absorptive roots at the less warm soils was probably due to the rapid and extensive proliferation into peat soils to enhance resource uptake.

\section{Conclusions}

Here, we detected tendencies in absorptive root morphological traits, such as SRA, SRL, BI, and RTD, in both examined tree species, Downy birch and Norway spruce, along with distance gradient from the ditch. Irrespective of tree species, SRA increased while RTD decreased toward higher distances from the ditch, indicating an acclimation in absorptive roots of trees to soil differences along with distances from the ditch. However, in this study, we could not show the variability in soil properties caused by distance from the ditch. There may exist other factors that influenced the soil local hydrology and microclimate rather than ditch distance, and these should be taken into consideration by future studies in drained peatland forests. We also pointed out the influence of soil physical and chemical factors, such as peat depth, $\mathrm{pH}$, and temperature, on the species-specific responses of absorptive root morphology in birch and spruce growing at similar drained histosols.

Nevertheless, we showed that evaluating absorptive root morphology alone is not a good indicator for describing changes in root foraging along with distances from the ditch. These absorptive root morphological traits should be further used in much wider analyses, such as root nutrient uptake capacity and with the associated ECM fungal communities, to better predict patterns in the root acclimation of trees and forest functioning at drained stands. 
Supplementary Materials: The following supporting information can be downloaded at: https: / / www.mdpi.com/article/10.3390/f13010112/s1, Figure S1A-F: Soil volumetric water content (VWC, $\mathrm{m}^{3} \mathrm{~m}^{-3}$ ) measured with a ProCheck reader equipped with a GS3 sensor (Decagon Devices Inc.) at sampling plots of 5, 15, 40, and $80(\mathrm{~m})$ distances from the ditch of replicate stands for birch (B1-B3) and spruce (S1-S3) and with reflectometers (model CS615, Campbell Scientific Inc., Logan, UT, USA) at sampling plots 5 and 40, of replicate stands B2 and S1, during April-October 2015, Figure S2: The sum of monthly precipitation $(\mathrm{mm})$ for 2015 and 2018 and the means \pm standard errors of the soil VWC from CR1000 logger data of plots 5 and 40, and replicate stands B2 and S1, from April to October 2015 and 2018, Figure S3A,B: The means of soil VWC for birch and spruce at sampling plots $(5,15,40$, and 80) averaged over relevant replicate stands during April-October 2015, Figure S4: Relationship between fine root biomass and stand basal area in all sampling plots in Norway spruce, Table S1: The means \pm standard errors of absorptive root morphological traits of sampling plots (5, 15, 40, and 80) in replicate stands for birch (B1-B3) and spruce (S1-S3), and of all sampling plots per birch and spruce replicate stand studied in 2018, Table S2: Pearson's correlation analyses between soil parameters of the forest stands for birch and spruce, Table S3: The effects of forest stands and distance from the ditch $(\mathrm{m})$ on absorptive root morphological traits in birch and spruce perfomed by general linear model (GLM).

Author Contributions: Conceptualization, I.O.; methodology, fieldwork, laboratory work, data analyses, I.O., A.R., M.M. and G.R.-O.; forest soil and stand measurements, I.O., M.T., M.M., A.T., A.R. and G.R.-O.; study site design and experimental setup, I.O., M.T., M.M., V.U. and Ü.M.; writing-original draft preparation, A.R.; writing-review and editing, A.R., M.T., M.M., G.R.-O., A.T., Ü.M. and I.O.; supervision, I.O.; funding acquisition I.O. and Ü.M. All authors have read and agreed to the published version of the manuscript.

Funding: The study was funded by Estonian Research Agency grant PRG916 and PRG352; V.U. was supported by PRG681 and A.T. by PRG1434, Estonian State Forest Management Centre (project "Carbon and nitrogen cycling in the forest with altered water regime", 2013-2016).

Data Availability Statement: The data presented in this study are available on request from the corresponding author.

Acknowledgments: The authors express their thanks to Tõnu Oja, Institute of Geoinformatics and Cartography at University of Tartu, for his constructive feedback and valuable comments. This study was supported by the Dora Plus program for Azadeh Rezapour personal scholarship.

Conflicts of Interest: The authors declare no conflict of interest.

\section{References}

1. Sikström, U.; Hökkä, H. Interactions between soil water conditions and forest stands in boreal forests with implications for ditch network maintenance. Silva Fenn. 2016, 50, 1416. [CrossRef]

2. Becker, H.; Aosaar, J.; Varik, M.; Morozov, G.; Aun, K.; Mander, Ü.; Soosaar, K.; Uri, V. Annual net nitrogen mineralization and litter flux in well-drained downy birch, Norway spruce and Scots pine forest ecosystems. Silva Fenn. 2018, 52, 10013. [CrossRef]

3. Raudsaar, M.; Kaia-Liisa, S.; Valgepea, M. Yearbook Forest; Estonian Environment Agency: Tartu, Estonia, 2016.

4. Gustavsen, H.G.; Heinonen, R.; Paavilainen, E.; Reinikainen, A. Growth and yield models for forest stands on drained peatland sites in southern Finland. For. Ecol. Manag. 1998, 107, 1-17. [CrossRef]

5. Macdonald, S.E.; Yin, F. Factors influencing size inequality in peatland black spruce and tamarack: Evidence from post-drainage release growth. J. Ecol. 1999, 87, 404-412. [CrossRef]

6. Miina, J. Spatial growth model for Scots pine on drained peatland. Silva Fenn. 1994, 28, 15-27. [CrossRef]

7. Hökkä, H.; Laurén, A.; Stenberg, L.; Launiainen, S.; Leppä, K.; Nieminen, M. Defining guidelines for ditch depth in drained Scots pine dominated peatland forests. Silva Fenn. 2021, 55, 10494. [CrossRef]

8. Roy, V.; Plamondon, A.P.; Bernier, P.Y. Draining forested wetland cutovers to improve seedling root zone conditions. Scand. J. For Res. 2000, 15, 58-67. [CrossRef]

9. Truu, M.; Nõlvak, H.; Ostonen, I.; Oopkaup, K.; Maddison, M.; Ligi, T.; Espenberg, M.; Uri, V.; Mander, Ü.; Truu, J. Soil Bacterial and Archaeal Communities and Their Potential to Perform N-Cycling Processes in Soils of Boreal Forests Growing on Well-Drained Peat. Front. Microbiol. 2020, 11, 591358. [CrossRef]

10. Laiho, R.; Vasander, H.; Penttilä, T.; Laine, J. Dynamics of plant-mediated organic matter and nutrient cycling following water-level drawdown in boreal peatlands. Glob. Biogeochem. Cycles 2003, 17, 111-119. [CrossRef]

11. Bhuiyan, R.; Minkkinen, K.; Helmisaari, H.-S.; Ojanen, P.; Penttilä, T.; Laiho, R. Estimating fine-root production by tree species and understorey functional groups in two contrasting peatland forests. Plant Soil 2017, 412, 299-316. [CrossRef] 
12. Iversen, C.M.; Childs, J.; Norby, R.J.; Ontl, T.A.; Kolka, R.K.; Brice, D.J.; McFarlane, K.J.; Hanson, P.J. Fine-root growth in a forested bog is seasonally dynamic, but shallowly distributed in nutrient-poor peat. Plant Soil 2018, 424, 123-143. [CrossRef]

13. Pregitzer, K.S.; DeForest, J.L.; Burton, A.J.; Allen, M.F.; Ruess, R.W.; Hendrick, R.L. Fine root architecture of nine North American trees. Ecol. Monogr. 2002, 72, 293-309. [CrossRef]

14. McCormack, M.L.; Dickie, I.A.; Eissenstat, D.M.; Fahey, T.J.; Fernandez, C.W.; Guo, D.; Helmisaari, H.S.; Hobbie, E.A.; Iversen, C.M.; Jackson, R.B. Redefining fine roots improves understanding of below-ground contributions to terrestrial biosphere processes. New Phytol. 2015, 207, 505-518. [CrossRef]

15. Ostonen, I.; Lõhmus, K.; Lasn, R. The role of soil conditions in fine root ecomorphology in Norway spruce (Picea abies (L.) Karst.). Plant Soil 1999, 208, 283-292. [CrossRef]

16. Guo, D.; Xia, M.; Wei, X.; Chang, W.; Liu, Y.; Wang, Z. Anatomical traits associated with absorption and mycorrhizal colonization are linked to root branch order in twenty-three Chinese temperate tree species. New Phytol. 2008, 180, 673-683. [CrossRef]

17. Zwetsloot, M.J.; Goebel, M.; Paya, A.; Grams, T.E.; Bauerle, T.L. Specific spatio-temporal dynamics of absorptive fine roots in response to neighbor species identity in a mixed beech-spruce forest. Tree Physiol. 2019, 39, 1867-1879. [CrossRef]

18. Ostonen, I.; Lõhmus, K.; Alama, S.; Truu, J.; Kaar, E.; Vares, A.; Uri, V.; Kurvits, V. Morphological adaptations of fine roots in Scots pine (Pinus sylvestris L.), silver birch (Betula pendula Roth.) and black alder (Alnus glutinosa (L.) Gaertn.) stands in recultivated areas of oil shale mining and semicoke hills. Oil Shale 2006, 23, 187-202.

19. Robles-Aguilar, A.A.; Pang, J.; Postma, J.A.; Schrey, S.D.; Lambers, H.; Jablonowski, N.D. The effect of pH on morphological and physiological root traits of Lupinus angustifolius treated with struvite as a recycled phosphorus source. Plant Soil 2019, 434, 65-78. [CrossRef]

20. Doi, R.; Tanikawa, T.; Wada, R.; Hirano, Y. Morphological traits of Chamaecyparis obtusa fine roots are sensitive to soil acid buffering capacity. Plant Soil 2020, 452, 73-85. [CrossRef]

21. Defrenne, C.E.; McCormack, M.L.; Roach, W.J.; Addo-Danso, S.D.; Simard, S.W. Intraspecific Fine-root trait-environment relationships across interior Douglas-fir forests of Western Canada. Plants 2019, 8, 199. [CrossRef]

22. Olmo, M.; Lopez-Iglesias, B.; Villar, R. Drought changes the structure and elemental composition of very fine roots in seedlings of ten woody tree species. Implications for a drier climate. Plant Soil 2014, 384, 113-129. [CrossRef]

23. Lozano, Y.M.; Aguilar-Trigueros, C.A.; Flaig, I.C.; Rillig, M.C. Root trait responses to drought are more heterogeneous than leaf trait responses. Funct. Ecol. 2020, 34, 2224-2235. [CrossRef]

24. Wang, P.; Diao, F.; Yin, L.; Huo, C. Absorptive roots trait plasticity explains the variation of root foraging strategies in Cunninghamia lanceolata. Environ. Exp. Bot. 2016, 129, 127-135. [CrossRef]

25. Leuschner, C.; Hertel, D.; Schmid, I.; Koch, O.; Muhs, A.; Hölscher, D. Stand fine root biomass and fine root morphology in old-growth beech forests as a function of precipitation and soil fertility. Plant Soil 2004, 258, 43-56. [CrossRef]

26. Fitter, A.H. Functional Significance of Root Morphology and Root System Architecture. Spec. Publ. Ser. Br. Ecol. Soc. 1985, 4, 87-106.

27. Lõhmus, K.; Oja, T.; Lasn, R. Specific root area: A soil characteristic. Plant Soil 1989, 119, 245-249. [CrossRef]

28. Weemstra, M.; Mommer, L.; Visser, E.J.; van Ruijven, J.; Kuyper, T.W.; Mohren, G.M.; Sterck, F.J. Towards a multidimensional root trait framework: A tree root review. New Phytol. 2016, 211, 1159-1169. [CrossRef] [PubMed]

29. Ostonen, I.; Truu, M.; Helmisaari, H.S.; Lukac, M.; Borken, W.; Vanguelova, E.; Godbold, D.L.; Lõhmus, K.; Zang, U.; Tedersoo, L. Adaptive root foraging strategies along a boreal-temperate forest gradient. New Phytol. 2017, 215, 977-991. [CrossRef]

30. Luke McCormack, M.; Adams, T.S.; Smithwick, E.A.; Eissenstat, D.M. Predicting fine root lifespan from plant functional traits in temperate trees. New Phytol. 2012, 195, 823-831. [CrossRef] [PubMed]

31. Kottke, I. Mycorrhizae-rhizosphere determinants of plant communities. In Plant Roots: The Hidden Half, 3rd ed.; Marcel Dekker: New York, NY, USA, 2002; pp. 919-932.

32. Isaac, M.E.; Martin, A.R.; de Melo Virginio Filho, E.; Rapidel, B.; Roupsard, O.; Van den Meersche, K. Intraspecific trait variation and coordination: Root and leaf economics spectra in coffee across environmental gradients. Front. Plant Sci. 2017, 8 , 1196. [CrossRef]

33. Liese, R.; Alings, K.; Meier, I.C. Root branching is a leading root trait of the plant economics spectrum in temperate trees. Front. Plant Sci. 2017, 8, 315. [CrossRef]

34. Beck, P.; Caudullo, G.; de Rigo, D.; Tinner, W. Betula Pendula, Betula Pubescens and Other Birches in Europe: Distribution, Habitat, Usage and Threats. In European Atlas of Forest Tree Species; San-Miguel-Ayanz, J., de Rigo, D., Caudullo, G., Houston Durrant, T., Mauri, A., Eds.; Publication Office of the European Union: Luxembourg, 2016; pp. 70-73.

35. Seppä, H.; Alenius, T.; Bradshaw, R.H.; Giesecke, T.; Heikkilä, M.; Muukkonen, P. Invasion of Norway spruce (Picea abies) and the rise of the boreal ecosystem in Fennoscandia. J. Ecol. 2009, 97, 629-640. [CrossRef]

36. Lõhmus, E. Estonian Forest Site Types; Valgus Publishers: Tallinn, Estonia, 1984. (In Estonian)

37. Schad, P. The International Soil Classification System WRB. 2014 Novel Methods for Monitoring and Managing Land and Water Resources in Siberia, 3rd ed.; Springer International Publishing: New York, NY, USA, 2016; pp. 563-571.

38. Clément, R.; Pärn, J.; Maddison, M.; Henine, H.; Chaumont, C.; Tournebize, J.; Uri, V.; Espenberg, M.; Günther, T.; Mander, Ü. Frequency-domain electromagnetic induction for upscaling greenhouse gas fluxes in two hemiboreal drained peatland forests. Appl. Geophys. 2020, 173, 103944. [CrossRef] 
39. Federation, Water Environmental, and APH Association. Standard Methods for the Examination of Water and Wastewater; American Public Health Association (APHA): Washington, DC, USA, 2005.

40. Ostonen, I.; Lõhmus, K.; Helmisaari, H.-S.; Truu, J.; Meel, S. Fine root morphological adaptations in Scots pine, Norway spruce and silver birch along a latitudinal gradient in boreal forests. Tree Physiol. 2007, 27, 1627-1634. [CrossRef]

41. Liu, B.; Li, H.; Zhu, B.; Koide, R.T.; Eissenstat, D.M.; Guo, D. Complementarity in nutrient foraging strategies of absorptive fine roots and arbuscular mycorrhizal fungi across 14 coexisting subtropical tree species. New Phytol. 2015, 208, 125-136. [CrossRef] [PubMed]

42. Yang, Z.; Zhou, B.; Ge, X.; Cao, Y.; Brunner, I.; Shi, J.; Li, M.-H. Species-Specific Responses of Root Morphology of Three Co existing Tree Species to Nutrient Patches Reflect Their Root Foraging Strategies. Front. Plant Sci. 2021, 11, 2322. [CrossRef] [PubMed]

43. Bauhus, J.; Messier, C. Soil exploitation strategies of fine roots in different tree species of the southern boreal forest of eastern Canada. Can. J. For. Res. 1999, 29, 260-273. [CrossRef]

44. Werger, L.; Bergmann, J.; Weber, E.; Heinze, J. Wind intensity affects fine root morphological traits with consequences for plant-soil feedback effects. AoB Plants 2020, 12, plaa050. [CrossRef]

45. Zhou, M.; Wang, J.; Bai, W.; Zhang, Y.; Zhang, W.H. The response of root traits to precipitation change of herbaceous species in temperate steppes. Funct. Ecol. 2019, 33, 2030-2041. [CrossRef]

46. McCormack, M.L.; Guo, D. Impacts of environmental factors on fine root lifespan. Front. Plant Sci. 2014, 5, 205. [CrossRef]

47. Young, K.L.; Woo, M.-k.; Edlund, S.A. Influence of local topography, soils, and vegetation on microclimate and hydrology at a high Arctic site, Ellesmere Island, Canada. Arct. Antarct. Alp. Res. 1997, 29, 270-284. [CrossRef]

48. Waddington, J.; Morris, P.; Kettridge, N.; Granath, G.; Thompson, D.; Moore, P. Hydrological feedbacks in northern peatlands. Ecohydrology 2015, 8, 113-127. [CrossRef]

49. Leppä, K.; Korkiakoski, M.; Nieminen, M.; Laiho, R.; Hotanen, J.-P.; Kieloaho, A.-J.; Korpela, L.; Laurila, T.; Lohila, A.; Minkkinen, $\mathrm{K}$. Vegetation controls of water and energy balance of a drained peatland forest: Responses to alternative harvesting practices. Agric. For. Meteorol. 2020, 295, 108198. [CrossRef]

50. Bardgett, R.D. The Biology of Soil: A Community and Ecosystem Approach; Oxford University Press: Oxford, UK, 2005 ; p. 242.

51. Fang, Y.; Wang, F.; Chen, J.; Lin, C.; Lin, X. Microbial responses in a cold waterlogged paddy field to different distances from a drainage ditch. Chil. J. Agric. Res. 2017, 77, 87-94. [CrossRef]

52. Qiu, S.; Wang, M.; Wang, F.; Chen, J.; Li, X.; Li, Q.; Lin, C.; Lin, X. Effects of open drainage ditch design on bacterial and fungal communities of cold waterlogged paddy soils. Braz. J. Microbiol. 2013, 44, 983-991. [CrossRef]

53. Freschet, G.T.; Valverde-Barrantes, O.J.; Tucker, C.M.; Craine, J.M.; McCormack, M.L.; Violle, C.; Fort, F.; Blackwood, C.B.; Urban-Mead, K.R.; Iversen, C.M. Climate, soil and plant functional types as drivers of global fine-root trait variation. J. Ecol. 2017, 105, 1182-1196. [CrossRef]

54. Marañón, T.; Navarro-Fernández, C.M.; Gil Martínez, M.; Domínguez, M.T.; Madejón, P.; Villar Montero, R. Variation in morphological and chemical traits of Mediterranean tree roots: Linkage with leaf traits and soil conditions. Plant Soil 2020, 449, 389-403. [CrossRef]

55. Parts, K.; Tedersoo, L.; Schindlbacher, A.; Sigurdsson, B.D.; Leblans, N.I.; Oddsdóttir, E.S.; Borken, W.; Ostonen, I. Acclimation of fine root systems to soil warming: Comparison of an experimental setup and a natural soil temperature gradient. Ecosystems 2019, 22, 457-472. [CrossRef]

56. Onwuka, B.; Mang, B. Effects of soil temperature on some soil properties and plant growth. Adv. Plants Agric. Res. 2018, 8, 34. [CrossRef] 